\title{
Kajian Potensi Limbah Pertanian Sebagai Sumber Karbon Pada Produksi Avicelase dan CMCase dari Bacillus circulans
}

\author{
Amrullah Hamdan Rahmadani dan Evi Susanti* \\ Jurusan Kimia Fakultas Matematika dan Ilmu Pengetahuan Alam \\ Universitas Negeri Malang \\ Jln. Semarang 5 Malang, Jawa Timur 60265 \\ *Email: esusanti.kim@gmail.com
}

\begin{abstract}
Abstrak
Avicelase dan CMCase mewakili aktivitas eksoselulase dan endoselulase, termasuk dua dari tiga jenis selulase dalam sistem selulase yang dihasilkan oleh Bacillus circulans. Ekspresi keduanya sangat dipengaruhi oleh jumlah dan jenis sumber karbon dalam media produksi. Penelitian ini bertujuan mengetahui jenis dan konsentrasi limbah pertanian terbaik untuk menghasilkan avicelase dan CMCase dari B. circulans serta kemampuan sistem selulase tersebut untuk mendegradasi substrat lignoselulosa. Limbah pertanian yang diteliti berupa ampas tebu, bonggol jagung dan sekam. Limbah pertanian tersebut digunakan sebagai satu-satunya sumber karbon pada media produksi. Avicel digunakan sebagai sumber karbon pembanding. Aktivitas avicelase dan CMCase ditentukan berdasar jumlah gula pereduksi yang dihasilkan dengan menggunakan metoda Somogy-Nelson. Hasil penelitian menunjukkan bahwa semua limbah pertanian yang diteliti berpotensi sebagai sumber karbon yang lebih baik dibandingkan dengan avicel untuk produksi avicelase dan CMCase dari B. circulans. Limbah pertanian yang terbaik adalah ampas tebu. Penggunaan ampas tebu pada konsentrasi 0,5\% menghasilkan aviselase dan CMCase sebesar 309,39 dan 405,48 U/mL. Sistem selulase yang dihasilkan mampu mendegradasi ampas tebu, bonggol jagung dan sekam.
\end{abstract}

Kata kunci : avicelase, CMCase, limbah pertanian, sumber kabon, Bacillus circulans

\begin{abstract}
Avicelase and CMCase activity represent exocellulase and endocellulase, including two of the three types of cellulase in the cellulase system produced by Bacillus circulans. Expression both of them strongly influenced by the amount and type of carbon source in the production medium. The aims of this research were to determine the type and concentration of the best agricultural waste to generate avicelase and CMCase from B. circulans and their ability to degrade lignocellulosic substrates. Studied agricultural wastes are bagasse, corn stalks and husks. Agricultural waste is used as the sole carbon source in media production. Avicel is used as a comparable carbon source. Avicel and CMCase activity are determined based on the amount of the reducing sugars is generated by using the method of Somogy - Nelson. The results showed that all the studied agricultural waste was a potential carbon source better than ethical for avicelase and CMCase production from B. circulans. Agricultural waste bagasse was the best one. The use of $0.5 \%$ bagasse produce CMCase and aviselase at 309.39 and $405.48 \mathrm{U} / \mathrm{mL}$ respectively. The resulting system was able to degrade bagasse, corn stalks and husks.
\end{abstract}

Keywords : avicelase, CMCase, agricultural waste, carbon sources, Bacillus circulans

\section{PENDAHULUAN}

Selulase merupakan salah satu enzim komersial yang memiliki nilai jual sangat tinggi. Dalam katalog Merck (2011), harga selulase (cellulose Onozuka R-10 dari Tricoderma viride) kemasan $5 \mathrm{~g}$ sekitar \$ 3.000, dan kemasan $25 \mathrm{~g}$ selulase sekitar $\$ 12.000$. Penjualan selulase terus mengalami pertumbuhan hingga $4 \%$ per tahun. Enzim selulase secara luas digunakan dalam berbagai industri yaitu produksi makanan, tekstil, loundry, pembuatan roti dan bir serta industri kertas (T, Padmavathi et al., 2012).

Avicelase (sellobiohidrolase, eksoselulase atau ekso-1,4- $\beta$-D-glukanase), CMCase (endoselulase, endoglukanase atau 
endo-1,4 $\beta$-D-glukanase) dan aktivitas selulase yang lain yaitu sellobiase ( $\beta$-glukosidase) bersinergi dalam proses degradasi selulosa secara alami. Eksoglukanase bekerja terhadap ujung pereduksi dan nonpereduksi rantai polisakarida selulosa atau memutus ikatan ( $\beta$ $1,4)$ glikosidik pada ujung-ujung selulosa yang berbentuk kristalin dan menghasilkan selobiosa sebagai produk utama dan rantai selulosa yang lebih pendek. Endoglukanase akan memutus secara acak bagian dalam selulosa yang berbentuk amorf sehingga menghasilkan oligosakarida yang bervariasi panjangnya dan menghasilkan ujung rantai baru. Enzim $\beta$-glukosidase akan menghidrolisis selobiosa menjadi monomermonomer glukosa (Lynd et al., 2002).

Mikroba selulolitik mampu menghasilkan lebih dari satu jenis aktivitas selulase (sistem selulase). Setiap mikroba selulolitik menghasilkan kompleksitas sistem selulase yang berbeda. Kelompok Bacillus sp. diketahui mampu menghasilkan sistem selulase yang komplek. Waeonukul et al. (2007) dan Susanti (2001) melaporkan bahwa B. circulans strain berbeda yang tumbuh dalam media yang mengandung avicel (mikrokristalin selulosa) menghasilkan sistem selulase yang memiliki aktivitas karboksimetilselulase (CMCase) dan avicelase.

Menurut Bhat (1997) terdapat dua jenis selulase yakni selulase konstitutif dan indusibel. Selulase konstitutif diproduksi secara terus menerus dan kadarnya di dalam sel sangat rendah sedangkan selulase indusibel diproduksi jika ada suatu induser yang sesuai. Proses induksi pada selulase indusibel diawali dengan terjadinya hidrolisis selulosa yang terdapat dalam media produksi oleh selulase konstitutif menjadi gula terlarut (soluble sugar). Gula terlarut tersebut diduga sebagai true inducer yang nantinya memasuki dinding sel dan secara langsung ataupun tidak langsung mempengaruhi pengikatan protein repressor pada DNA yang mendorong terjadinya ekspresi gen selulase indusibel.

Beberapa jenis karbohidrat telah digunakan sebagai induser. Selulosa adalah induser alamiah yang banyak digunakan. Karbohidrat lain yaitu karboksimetilselulosa (CMC), sophomers, lactose dan avicel juga telah digunakan sebagai induser (Bhat, 1997).
Konsentrasi selulosa juga memengaruhi pertumbuhan mikroba selulolitik dan produksi selulasenya Pada umumnya jumlah sumber karbon yang optimum untuk produksi selulase sebesar $1 \%$, pada kondisi di bawah atau di atas konsentrasi tersebut produksi selulase menurun (Moosavi-Nasab \& Majdi-Nasab, 2007). Susanti (2011) menunjukkan produksi avicelase dan CMCase dari $B$. circulans strain lokal dalam media Berg meningkat dengan penggunaan avicel sebagai sumber karbon dan peningkatan maksimal hingga konsentrasi avicel sebesar $0,5 \%$.

Limbah pertanian seperti ampas tebu, bonggol jagung dan sekam mengandung selulosa yang cukup tinggi yaitu sekitar $\pm 30-$ $35 \%$ (Hambali et.al, 2007) . Sudto et al., (2008) melaporkan bahwa pada beberapa penelitian limbah pertanian potensial digunakan sebagai sumber karbon untuk produksi CMCase. Pada penelitian ini dibandingkan produksi avicelase dan CMCase dari $B$. circulans menggunakan sumber karbon beberapa limbah pertanian dengan avicel. Hasil yang diperoleh dapat dikembangkan untuk memformulasikan media produksi sistem selulase yang lebih murah dan meningkatkan ketermanfaatan limbah pertanian.

\section{METODOLOGI PENELITIAN}

\section{Preparasi Sumber Karbon dan Substrat Lignoselulosa}

Limbah pertanian yang akan menjadi sumber karbon dan substrat lignoselulosa berupa bonggol jagung dan sekam padi dikeringkan dengan cara di jemur beberapa hari pada terik matahari untuk menghilangkan kadar airnya. Setelah benar-benar kering, bonggol jagung dan sekam padi dihaluskan menggunakan blender, sedangkan ampas tebu tidak perlu dihaluskan karena sudah berbentuk potongan kecil-kecil. Hasil ini lansung digunakan sebagai sumber karbon, sedangkan untuk substrat lignoselulosa dilanjutkan dengan pencucian menggunakan air panas sebanyak tiga kali untuk menghilangkan kadar glukosa terlarut. 


\section{Produksi Avicelase dan CMCase dari Bacillus circulans dengan Berbagai Sumber Karbon}

Cara kerja merujuk penelitian sebelumnya (Susanti, 2011) yaitu sebanyak 5 ose Bacillus circulans dari medium nutrien agar diinokulasikan ke dalam $10 \mathrm{~mL}$ medium nutrien Broth cair secara aseptis, diinkubasi semalam pada $37^{\circ} \mathrm{C}$ dan $86 \mathrm{rpm}$ hingga diperoleh starter. Sebanyak $2 \mathrm{~mL}$ starter diinokulasikan secara aseptis masing-masing ke dalam $100 \mathrm{~mL}$ medium garam mineral Berg cair $\mathrm{pH} 9$ yang mengandung $0 ; 0,1 ; 0,3 ; 0,5$ dan 0,6\% sumber karbon. Kultur biakan diinkubasi pada $37^{\circ} \mathrm{C}$ dengan kecepatan 85 rpm selama 5 hari. Kultur biakan disentrifugasi $3000 \mathrm{rpm}$ selama 20 menit. Sentrat yang diperoleh merupakan ekstrak kasar enzim selulase yang mengandung avicelase dan CMCase.

\section{Penentuan Aktivitas Avicelase dan CMCase}

Sebanyak $2 \mathrm{~mL}$ ekstrak kasar enzim dicampur dengan $2 \mathrm{~mL}$ substrat (avicel dan CMC 1\%) dalam buffer fosfat $\mathrm{pH} 7,0$, dan 1 $\mathrm{mL}$ buffer fosfat $\mathrm{pH} 7,0$, diinkubasi pada $45^{\circ} \mathrm{C}$ selama 120 menit. Ujung pereduksi yang terbentuk sebagai hasil hidrolisis diukur dengan metode Somogyi-Nelson.

Aktivitas avicelase dan CMCase dinyatakan dalam Unit. Unit (U/mL) didefinisikan sebagai jumlah ujung pereduksi yang dilepas $(\mu \mathrm{g})$ per $\mathrm{mL}$ ekstrak kasar enzim per jam waktu inkubasi enzim substrat pada kondisi percobaan (Alam, 2004). Pengukuran aktivitas enzim dilakukan dengan mengkonversikan nilai absorbansi yang diperoleh ke dalam persamaan linier kurva standar gula pereduksi, kemudian dihitung dengan rumus:

Dimana :

$$
\text { Aktivitas }=\frac{x \cdot V}{p \cdot q}
$$

$\mathrm{x}=$ konsentrasi gula pereduksi (ppm)

$\mathrm{p}=$ jumlah enzim $(\mathrm{mL})$

$\mathrm{V}=$ volume total percobaan pada tiap tabung $(\mathrm{mL})$

$\mathrm{q}=$ waktu reaksi (jam)

\section{Penentuan Kadar Glukosa dengan Metode Somogyi-Nelson}

Pada masing-masing $1 \mathrm{~mL}$ sampel (gula pereduksi yang terbentuk sebagai hasil hidrolisis) ditambahkan $1 \mathrm{~mL}$ pereaksi Nelson aduk homogen. Kemudian dipanaskan dalam penangas air mendidih selama 20 menit. Campuran tersebut kemudian didinginkan dalam suhu ruang dan ditambahkan $1 \mathrm{~mL}$ pereaksi arsenomolibdat. Ditambahkan aquades sebanyak $7 \mathrm{~mL}$ untuk mengurangi kepekatan. Absorbansi larutan diukur pada panjang gelombang $540 \mathrm{~nm}$.

\section{Uji Kemampuan Mendegradasi Substrat Lignoselulosa}

Masing-masing sebanyak $0,1 \mathrm{~g}$ serbuk lignoselulosa berupa ampas tebu, bonggol jagung, dan sekam padi dicampur dengan 4 $\mathrm{mL}$ ekstrak kasar sistem selulase dan $6 \mathrm{~mL}$ buffer fosfat $\mathrm{pH} 7,0$, di shaker pada suhu $50^{\circ} \mathrm{C}$, selama 2 jam. Setelah reaksi dihentikan, campuran disentrifugasi $3000 \mathrm{rpm}$ selama 20 menit. Sentrat yang diperoleh diukur kadar gula pereduksinya menggunakan metode Somogyi-Nelson.

Kemampuan sistem selulase mendegradasi substrat lignoselulosa (ampas tebu, bonggol jagung, dan sekam padi) dalam Waenukul et al. (2007) dinyatakan sebagai banyaknya gula pereduksi yang dihasilkan (mg gula reduksi)

Kemampuan mendegradasi (mg gula pereduksi $)=[$ gula pereduksi $](\mathrm{ppm}) \times \mathrm{V}$ Volume total percobaan $(\mathrm{L})$

\section{HASIL DAN PEMBAHASAN}

Hasil penelitian menunjukkan bahwa jenis sumber karbon yang berbeda menghasilkan profil aktivitas avicelase dan CMCase yang berbeda pula. Aktivitas CMCase dan avicelase pada masing-masing sumber karbon limbah pertanian yakni ampas tebu, bonggol jagung, dan sekam padi sudah mulai tampak pada konsentrasi $0,1 \%$, sedangkan dengan induser avicel belum. Aktivitas CMCase dan avicelase yang dihasilkan menggunakan sumber karbon limbah pertanian memiliki nilai aktivitas yang jauh lebih tinggi dibandingkan dengan menggunakan avicel (Gambar 1). Perbandingan aktivitas avicelase pada sumber karbon limbah pertanian dibandingkan dengan avicel yakni sebesar 6:1 untuk ampas tebu, 5:1 untuk bonggol jagung dan 4:1 untuk sekam padi, sedangkan aktivitas CMCase sebesar 4:1 untuk ampas tebu, 3:1 untuk bonggol jagung dan sekam padi (Tabel 1). 
Tabel 1. Perbandingan aktivitas avicelase dan CMCase antara sumber karbon limbah pertanian dengan Avicel

\begin{tabular}{lllll}
\hline Induser & \multicolumn{2}{c}{ CMCase } & \multicolumn{2}{c}{ Avicelase } \\
\cline { 2 - 5 } & $\begin{array}{l}\text { Aktivitas Enzim } \\
\text { (U/mL) }\end{array}$ & $\begin{array}{l}\text { Perbandingan } \\
\text { dengan Induser } \\
\text { Avicel }\end{array}$ & $\begin{array}{l}\text { Aktivitas } \\
\text { Enzim (U/mL) }\end{array}$ & $\begin{array}{l}\text { Perbandingan } \\
\text { dengan Induser } \\
\text { Avicelase }\end{array}$ \\
\hline Avicel & 55,56 & & 104,17 & \\
Ampas tebu & 309,39 & $6: 1$ & 405,48 & $4: 1$ \\
Bonggol jagung & 277,81 & $5: 1$ & 373,22 & $3: 1$ \\
Sekam padi & 246,56 & $4: 1$ & 341,31 & $3: 1$ \\
\hline
\end{tabular}
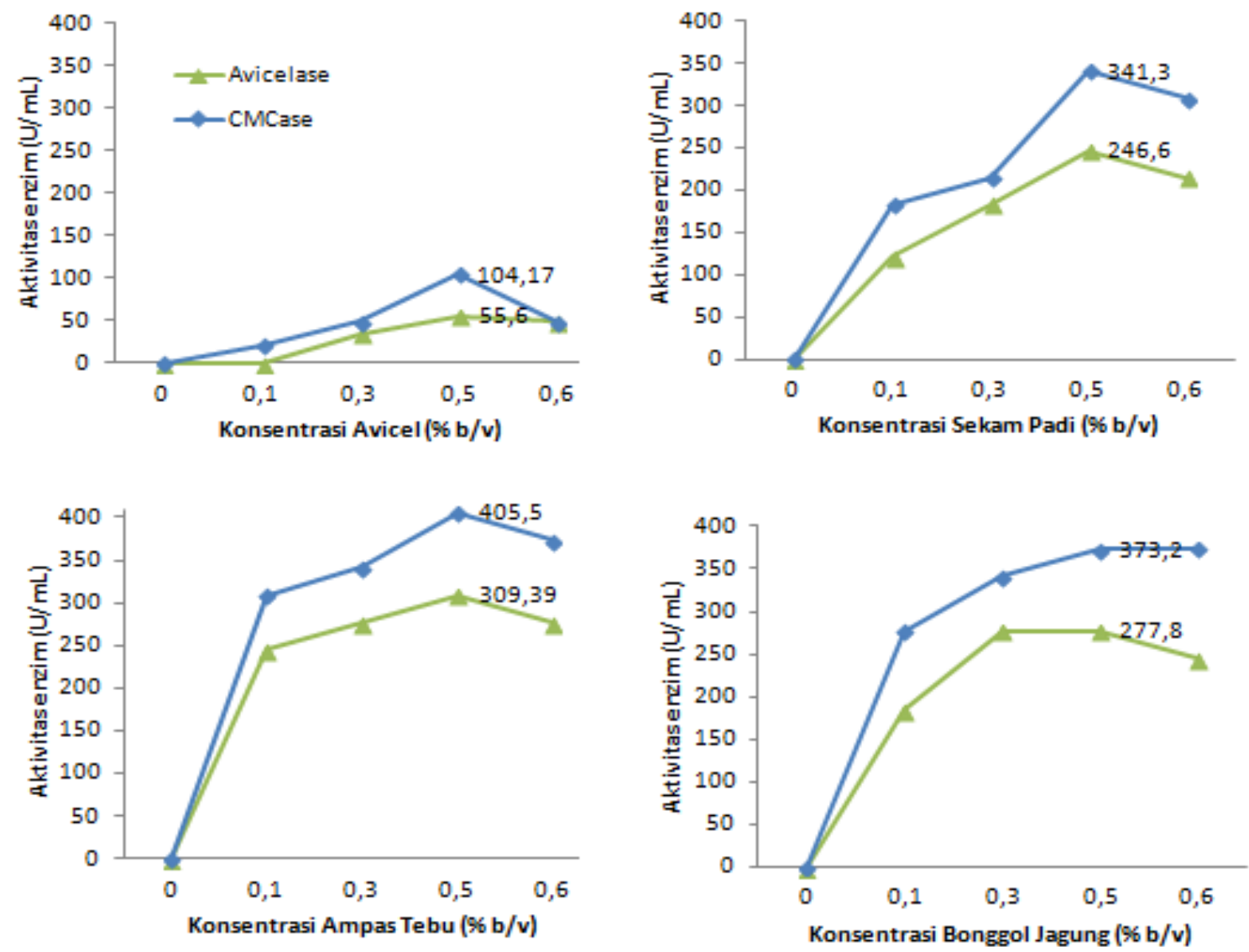

Gambar 1. Aktivitas avicelase dan CMCase yang dihasilkan Bacillus circulans dalam media produksi menggunakan sumber karbon: avicel, ampas Tebu, sekam padi dan bonggol jagung ( tanda segitiga $=$ aktivitas $\mathrm{CMCase}$ dan wajik $=$ avicelase).

Avicel merupakan selulosa kristalin yang memiliki interaksi antar fibril selulosa sangat rapat, sedangkan limbah pertanian bukan merupakan selulosa murni melainkan lignoselulosa. Selulosa dalam limbah pertanian cenderung merupakan selulosa amorf. Pada umumnya selulase lebih mudah menghidrolisis bagian amorf pada selulosa dibandingkan bagian yang kristalin. Jika dikaitkan dengan hipotesis yang dinyatakan Bhat (1997) maka diduga perbedaan struktur selulosa pada avicel dengan limbah pertanian yang menyebabkan profil avicelase dan CMCase yang dihasilkan berbeda. Struktur avicel sulit untuk dihidrolisis selulase konstitutif sehingga pada jumlah yang sama pembentukan "true induser" lebih rendah. Semakin rendah jumlah "true induser" maka proses induksi terhadap produksi selulase indusibel (avicelase dan CMCase) juga lamban. Sebaliknya, semakin tinggi jumlah "true induser" maka semakin cepat proses induksi sehingga produksi selulase juga tinggi. Dugaan ini dikuatkan melalui penelitian Akhtar (1998) yang melaporkan bahwa gula reduksi (menunjukkan adanya aktivitas selulase) yang dihasilkan isolat Streptomyces 


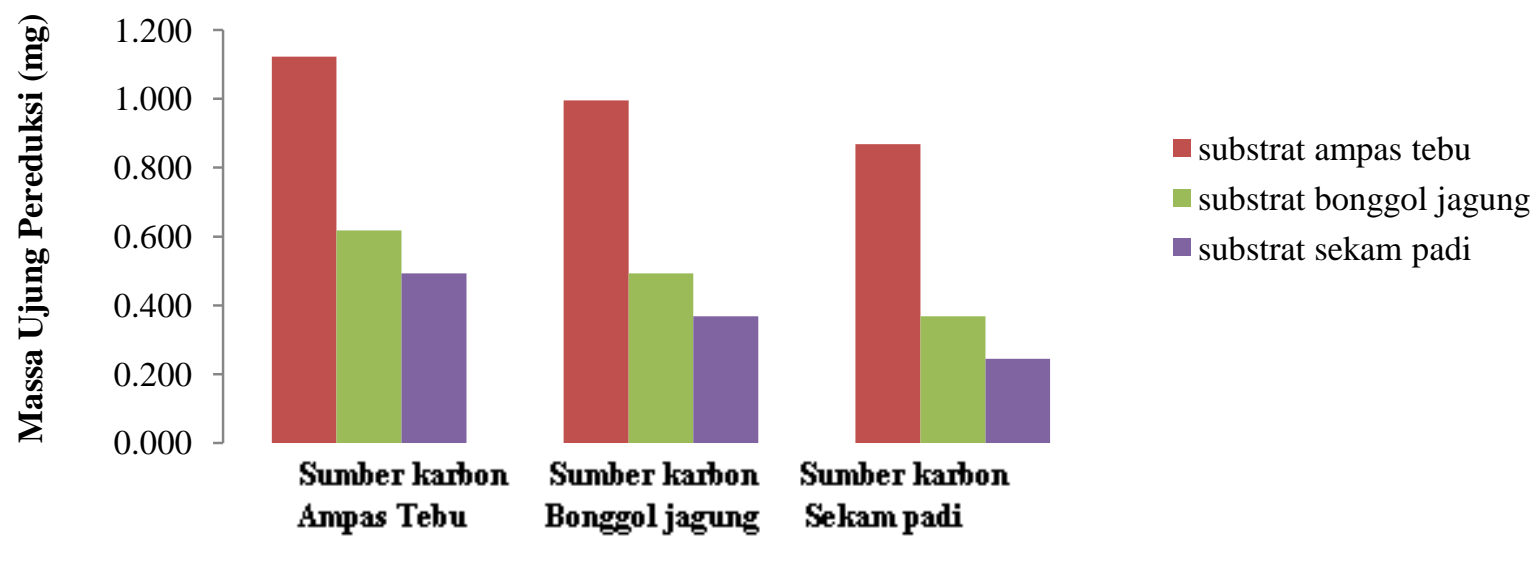

Gambar 2. Kurva Kemampuan Ekstrak kasar Sistem Selulase dari Bacillus circulans Menghidrolisis Berbagai Substrat Lignoselulosa yang Berturut-turut Diproduksi dalam Sumber Karbon: Ampas Tebu, Bonggol Jagung, dan Sekam Padi.

omiyaensis yang ditumbuhkan dalam media dengan sumber karbon CMC yang merupakan selulosa amorf lebih tinggi dibandingankan avicel.

Konsentrasi optimum avicel, ampas tebu dan sekam padi sebagai sumber karbon yaitu $0,5 \%$. Walaupun aktivitas CMCase pada sumber karbon bonggol jagung masih meningkat hingga konsentrasi 0,6\%, tetapi aktivitas avicelasenya menurun. Maka disimpulkan bahwa konsentrasi optimum bonggol jagung sebagai sumber karbon pada produksi avicelase dan CMCase dari Bacillus circulans sebesar 0,5\% (Gambar 1). Hasil ini sejalan dengan Akhtar (1998) yang menyatakan bahwa selulase yang diproduksi oleh Bacillus subtilis optimum dengan penggunaan $0,5 \%$ pada berbagai sumber karbon yaitu arabinosa, xilosa, avicel dan CMC; dan Susanti (2011) yang menyatakan bahwa avicelase dan CMCase yang diproduksi oleh Bacillus circulans dengan sumber karbon avicel optimum pada konsentrasi 0,5\%. Berdasarkan hasil penelitian ini maka dapat disimpulkan bahwa limbah pertanian: ampas tebu, bonggol jagung, dan sekam padi sangat berpotensi digunakan sebagai sumber karbon untuk produksi avicelase dan CMCase dari Bacillus circulans.

Aktivitas tertinggi dari ketiga jenis induser alamiah dihasilkan oleh induser ampas tebu yaitu dengan aktivitas CMCase rata-rata sebesar 405,48 U/mL dan aktivitas avicelase rata-rata sebesar 309,39 U/mL. Hal ini diduga karena kandungan selulosa pada ampas tebu (35\%) lebih besar daripada bonggol jagung
(32 \%) dan sekam padi (34\%) sehingga kemungkinan terbentuknya true induser lebih tinggi.

Sistem selulase yang memiliki kemampuan tinggi mendegradasi substrat lignoselulosa memiliki aktivitas avicelase dan CMCase yang tinggi. Hasil penelitian ini menunjukkan bahwa ada hubungan linier antara tingginya aktivitas avicelase dan CMCase dengan kemampuan menghidrolisis substrat lignoselulosa. Aktivitas avicelase dan CMCase pada sistem selulase yang dihasilkan dalam media produksi dengan sumber karbon ampas tebu tertinggi dibandingkan bonggol jagung dan sekam memiliki kemampuan mendegradasi substrat lignoselulosa yang paling tinggi pula (Gambar 2).

\section{SIMPULAN}

Semua limbah pertanian yang diteliti berpotensi sebagai sumber karbon yang lebih baik dibandingkan dengan avicel untuk produksi avicelase dan CMCase dari Bacillus circulans. Limbah pertanian yang terbaik adalah ampas tebu. Penggunaan ampas tebu pada konsentrasi $0,5 \%$ menghasilkan aviselase dan CMCase sebesar 309,39 dan 405,48 U/mL. Sistem selulase yang dihasilkan mampu mendegradasi ampas tebu, bonggol jagung dan sekam.

\section{DAFTAR PUSTAKA}

Akhtar, M. S. 1998. Bioconversion of Cellulosic Materials by The Action of Microbial 
Cellulase. Thesis. Institute of Chemistry University of The Punjab.

Bhat, S., R. A. Hutson, E. Owen, and M. K. Bhat. 1997. Determination of immunological homology between cellulosome subunits and cloned endoglucanases and xylanases of Clostridium thermocellum.

Hambali, E., Mujdalipah, S., Tambunan, A.H., Pattiwiri, A.W. \& Hendroko, R. 2007. Teknologi Bioenergi. Jakarta: Agro Media.

Lynd, L. R., Weimer, P. J., W. H. van Zyl and Pretorius, I. S. 2002. Microbial Cellulose Utilization: Fundamentals and Biotechnology. Microbiol. Mol. Biol. Rev. 66:506-577.

Merck. 2011. Katalog Harga Selulase (cellulose Onozuka R-10 Tricoderma viride).

Moosavi-Nasab, M. A \& Majdi-Nasab, M., 2007. Cellulase Production by Trichoderma reesei using Sugar Beet Pulp. Iran Agri. Research, 25 (2): 107-116
Sudto, A., Punyathiti, Y. And Pongslip, N. 2008. The Use Of Agriculture Waste As Substrates For Cell Growth And Carboxymethyl Cellulase (CMCase) Production by Bacillus subtilis, Escherichia coli and Rhizobium sp. KMITL Sci.Tech. J. Vol 8 No 2, p. 84-92

Susanti, E., 2011, Optimasi Produksi dan Karakterisasi Sistem Selulase dari Bacillus circulans Strain Lokal dengan Inducer Avicel, Jurnal Ilmu Dasar, Jember

T. Padmavathi, Nandym V. and Agarwal, P. 2012. Optimization of the medium for the production of cellulases by Aspergillus terreus and Mucor plumbeus. European Journal of Experimental Biology, vol 2 (4):1161-1170

Waeonukul, R., K. Rattanakhanokchai, and K. L. Kyu. 2007. Multiple Cellulases and Xylanases from Bacillus circulans B6 During Growth on Avicel Under an Aerobic Condition. Thai Journal of Biotechnology. p. 27-32 